\title{
Recombinant Interleukin-5
}

National Cancer Institute

\section{Source}

National Cancer Institute. Recombinant Interleukin-5. NCI Thesaurus. Code C590.

A recombinant therapeutic agent which is chemically identical to or similar to the

endogenous cytokine interleukin-5 (IL-5). Produced by T cells, IL-5 stimulates the growth,

differentiation, and activation of eosinophils, and promotes the conversion of B-cells into antibody- producing cells. ( $\mathrm{NCl} 04)$ 